\title{
Cinemas of the Other
}

\author{
By Latika Padgaonkar \\ Fall 2006 Issue of KINEMA
}

\section{Cinemas of the Other: A personal journey with film-makers from the Middle East and Central Asia.}

Cinemas of the Other is a film buff's delight. This set of extended, thoroughly researched interviews with twenty-seven renowned filmmakers from seven countries is accompanied by a pithy and useful biographical note on each one of her interviewees - just enough to give you a glimpse of their personality but never too long to give anything away. That something personal emerges from the lengthy interviews.

The word "interview," in fact, is perhaps a misnomer. With several of these filmmakers, D?nmez-Colin is "in conversation with." She dialogues with them, comments on their work; often, her observations are longer than their answers. She approaches her task with meticulous scholarship. To the reader, it is palpably clear that she has seen and studied the films of each director, followed his/her career graph and knows the social and political trends and issues that shake and stir their countries and their cinemas. The book, therefore, is not between filmmakers and a journalist but between an artist and an intelligent and aware researcher. D?nmez-Colin brings a good deal of cultural knowledge to the table - a distinct advantage that allows her to notice the macro and micro simultaneously.

Cinemas of the Other is a discovery through dialogue of filmmakers from five Central Asian countries Kazakhstan (4), Kyrgyzstan (5), Tajikistan (1), Turkmenistan (1) and Uzbekistan (2) - and two Muslim non-Arab countries - Iran (10), Turkey (5). The "other" in the title, explains G?n?l in her introduction, has a dual meaning: a) non-Western nations of the Islamic Middle East and Central Asia that are commonly perceived as a distinctly separate entity and b) the cinemas of these nations which are committed to voice social and political issues of their peoples and / or oppose, both in style and in content, dominant mainstream cinema inside and outside the country.

Whatever her reasons for the first point, it is the second that she keeps firmly in her line of vision as she cajoles the directors and gets them to pause, reflect and talk. Some issues recur in these dialogues as well they must, given their countries' recent political histories. One of these is freedom. Several filmmakers comment on the nature and quality of freedom they have been living through. Chingiz Aitmatov, the renowned Kirghiz writer (he fits into this book because the national cinema of Kyrgyzstan owes him much of its history - he was for a long time the President of the Cinematographers' Union, and "has given to the cinema more than a dozen of his most important works, often scripting or co-writing") calls cinema "just a dry little branch." For while there may be no censorship, such are the economic problems that "we have the illusion of liberty, not liberty." Iran's Mohsen Makhmalbaf believes that lack of freedom is the biggest problem of Iranian cinema.

Kazakh director Serik Aprimov puts his finger on a failing pulse: "When there was money, there was censorship. Now there is no censorship and no money. Cinemas in Almaty are closed one after the other. Not even American films are shown... TV stations buy old American movies for $\$ 1000$ and keep showing them year after year. I offered to show Aksuat for free but they said, 'No, life is hard enough without your films."”

Not all are agreed on the subtle workings of freedom. Asked whether the government controls the arts, Kirghiz director Aktan Abdykalykov exclaims: "Not at all. Absolutely not! And I am scared about that because control is order. You can avoid control. Things that are forbidden you have to avoid, which means that the artist has to be more concentrated to be more inventive. During the Soviet Union (sic), many films ended up on shelves, but still, films were made and these films were good. Perhaps it is easier to live in an authoritarian regime than in total freedom. Living in a free country, every individual needs to have a bigger chance, and I don't think our country is ready for that kind of freedom."

Some replies are evasive. The government completely subsidises 6 films a year, says Zulfikar Mussakov from Uzbekistan, and private studios no more than a couple. Does the government approve his scripts, since it 
finances his projects? "I have written many screenplays, if the authorities do not like some, I always have others." No use of the word "restriction" here, but the sense is clear enough.

Many of the filmmakers refer to the women's question. Mussakov feels filmmaking is not an occupation for women. "Many women directors lose from being a woman... you need hard nerves." In Iran, on the other hand, Rakshan Bani-Etemad states that the number of women making films in Iran is very large, while in the view of Yesim Ustaolu, Turkish women directors "do not give the woman's point of view. Just like men they are not very interested in making films about what really interests them.." Yet, the late Atif Yilmaz was eminently a director of women's films.

No special emphasis is given to the question of religion. But stray comments here and there are pointers to people's ways of being and living: Bahram Beyzai (Iran) says that his film The Stranger and the Fog was "very experimental and aggressive towards religion and tradition." In the view of Gennadi Bazarov (Kyrgyzstan), his people respect religious traditions but are not really believers. For Tolomush Okeev, also Kirghiz, Kazakh films are "introspective." They reflect the steppe mentality; Kirghiz films are "melancholic and brusque, typical of a mountain people. Uzbek films are extravagant, even kitsch." Manifestly, cultural differences have grown more pronounced since the end of the Soviet Union.

We know little of the questions of language that Central Asian directors have been grappling with. In Okeev's In The Sky of Our Childhood, the grandmother laments that her children speak Russian. "I even got into trouble because of that scene," confesses the director. "I was accused of being against the Russian language." Interestingly, Kirghiz was accepted as the official language in 1991, and there was the question of returning to the use of the Latin alphabet. "But nationalists do not understand the main purpose and try to turn it into a revolution... want to change everything overnight. After Independence we have had two enemies: Russian chauvinism and extreme patriotism.

Cinemas of the Other has all this and more. Once in a while, piquant personal comments on other directors are woven into exchanges on cinema. The mood in Central Asia is sombre. Fewer films than ever before, directors left to swim or sink in the new-found democracy and freedom. And the mood in Iran and Turkey is not exactly upbeat. But D?nmez-Colin is a determined and dogged interviewer, often pursuing her interlocutors over another year to update her dialogue. The book is a worthy successor to Women, Islam and Cinema published two years ago.

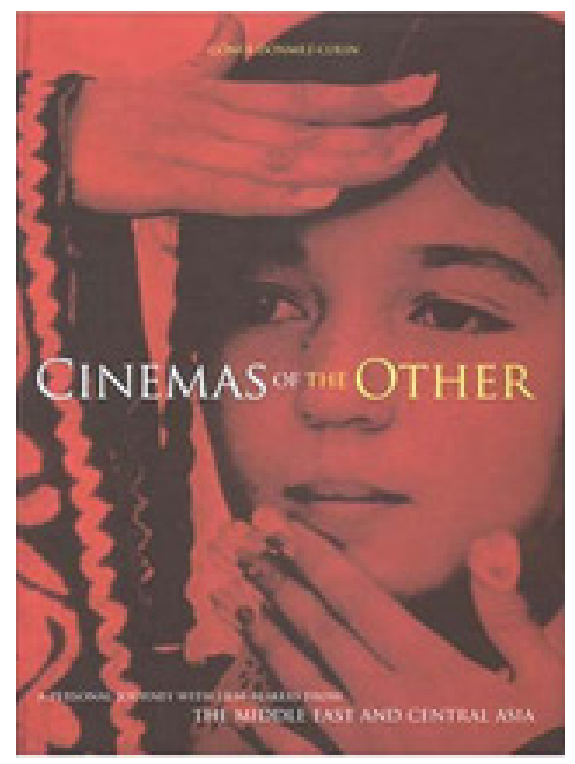

Figure 1: CINEMAS OF THE OTHER: A Personal Journey with Film-makers from the Middle East and Central Asia. Gönül Dönmez-Colin. New York: Intellect Books, 2006. 284 pp. ISBN: 1841501433. \$ 59.99 (hdbk). 


\section{Author Information}

Latika PADGAONKAR is the executive editor of Cinemaya, The Asian Film Quarterly and a columnist writing on cinema and literature. She has served on several film festivals juries. She was a National Information Officer for UNESCO in New Delhi (15 years) and a foreign correspondent in Paris for the Indian daily The Telegraph. 